\title{
Batı Anadolu'da Günlük Yağış Şiddetindeki Değişimler
}

\section{ismail AĞBAŞ ${ }^{1}$ (D), Ercan YEŞiLIRMAK ${ }^{*}$ (D)}

\author{
${ }^{1}$ Devlet Su işleri 21. Bölge Müdürlüğü, AYDIN
}

${ }^{2}$ Aydın Adnan Menderes Üniversitesi, Ziraat Fakültesi, Biyosistem Mühendisliği Bölümü, Arazi ve Su Kaynakları Anabilim Dalı, AYDIN

Öz: Atmosferde konsantrasyonu artan sera gazlarının neden olduğu küresel ısınma yirminci yüzyılın son çeyreğinden itibaren dünyanın en önemli çevre sorunu haline gelmiştir. Sıcaklık artışııın sadece yağış toplamlarında değil aynı zamanda ekstrem yağışlarda değişimlere, daha sık ve şiddetli sel ve kuraklık hadiselerine yol açması beklenmektedir. Küresel ısınma bağlamında, ülkemizdeki yağış toplamlarındaki değişimler oldukça geniş çaplı araştırma konusu olmasına karşın yağış şiddetlerindeki değişimler yeterince incelenmemiştir. Bu çalışmada, ülkemizin batısında yer alan 13 ildeki 32 istasyon için Meteoroloji Genel Müdürlüğü'nden sağlanan günlük yağış verileri, hafif yağış, orta kuvvette yağış, kuvvetli yağış, çok kuvvetli yağış, şiddetli yağış ve aşııı yağış olmak üzere altı farklı kategoriye ayrılmış ve her bir kategori için üç farklı indisin (yağışı gün sayısı, yağış miktarı, kategorideki yağışın toplam yağışa oranı) mevsimlik ve yıllık ölçekte 1966 ile 2011 arasındaki zamansal değişimleri ile çalışma alanındaki konumsal değişimleri incelenmiştir. Çalışma sonucunda, yaz mevsiminde çalışma alanının kuzeyinin, diğer mevsimlerde ise güneyinin daha fazla sel riskine sahip olduğu saptanmıştır. Zamansal değişim analizinde ise, hafif yağış kategorisinde yıllık ölçekte yağışı gün sayısı, yağış miktarı ve kategorideki yağışın toplam yağışa oranı için saptanan yaygın azalış eğilimleri haricinde diğer tüm kategori-indis-ölçek kombinasyonlarında \%95 düzeyinde istatistiksel olarak önemli bir değişim saptanmamışıı. Başka bir anlatımla, sıcaklık artışına rağmen ülkemizin batı kesimlerinde üst kategori yağışlarda önemli bir değişim meydana gelmediği saptanmıştır.

Anahtar Kelimeler: iklim değişikliği, zamansal analiz, yağışlı gün sayısı, yağış miktarı

\section{Variations of Daily Rainfall Intensity in Western Anatolia}

Abstract: Global warming associated with the increase of greenhouse gases in the atmosphere has become the most important environmental problem of the World since the last quarter of 20th century. Temperature increase is expected to result in changes not only in total rainfall amounts but also in extreme rainfall events, more frequent and intense flood and drought events. Under changing climate although how total rainfall amounts have changed in Turkey are extensively investigated, changes in rainfall intensities are not adequately examined. In this study, daily rainfall data recorded between 1966 and 2011 at 32 rainfall gaging stations located in 13 provinces of western Anatolia, Turkey, were supplied from the State Meteorological Service (MGM) and categorized into six classes, namely light, light-moderate, moderate-heavy, heavy, heavy-torrential and torrential. Then, for each category, spatial and monotonic temporal changes of three indices (number of rainy days, rainfall amount and the ratio of rainfall amount to total rainfall) were analyzed in seasonal and annual scales. Results showed that flood risk is more likely in northern part in summer and in southern part in other seasons. Temporal analysis showed that there is no statistically significant (at 95\% level) monotonic trend for all combinations of category-index-temporal scale, except a number of decreasing trends in light rainfall. It can be concluded that there has been no statistically significant change in daily rainfall intensities over western Anatolia (Turkey) over the period 1966-2011 although average temperature has increased.

Keywords: Climate change, temporal analysis, rainy days, rainfall amount

\section{GiRiş}

Sanayi devrimiyle birlikte ortaya çıkan antropojenik iklim değişikliği nedeniyle küresel ortalama sıcaklıktaki artışa paralel olarak, yağışlarda da değişimler söz konusudur. Yıllık toplam yağışlar, 1901-2005 arasında, Avustralya'da, Avrasya'da, Kuzey ve Güney Amerika'da artmış; Sahel'de, Afrika'nın Batısında, Akdeniz havzasında, Güney Amerika'nın batı kıyılarında azalmıştır (Homar ve ark., 2010). İklim değişikliğinin sadece toplam yağış miktarında değil aynı zamanda ekstrem yağış hadiselerinde de değişimlere yol açması beklenmektedir (Cubasch ve ark., 2013). Bunun nedeni, hava sıcaklığındaki artış sebebiyle atmosferin nem tutma kapasitesinin yükselmesi ve buna bağlı olarak hidrolojik döngünün hızlanmasıdır (Fowler ve Hennessy, 1995; Mishra ve Singh, 2010). Yağış miktarındaki zamansal ve mekânsal değişimlerin yüzey akışı, toprak nemini ve yer altı su rezervlerini etkilemesi söz konusudur (Kumar ve Jain, 2010). Yağış miktarında ve şiddetinde olası artışlar toprakları erozyona daha duyarlı hale getirebilecek ve şev stabilitesinin bozulmasına neden olabilecektir. Sel ve erozyon hadiselerinin frekansında ve şiddetindeki artışlar da daha fazla ekonomik zarara ve can kaybına yol açabilecektir. Ayrıca, yağış miktarındaki ve şiddetindeki değişimlerin, su

Sorumlu Yazar: eyesilirmak@adu.edu.tr. Bu çalışma yüksek lisans tez ürünüdür ve Aydın Adnan Menderes Üniversitesi Bilimsel Araştırma Projeleri birimi tarafından desteklenmiştir (Proje No: ZRF-15001)

Geliş Tarihi: 2 Aralık 2019

Kabul Tarihi: 29 Nisan 2020 
yapılarının planlanması, inşası ve işletimi ile su kaynakları yönetiminde yeni stratejilerin geliştirilmesini zorunlu kılabilecektir (Yeşilırmak ve ark., 2011).

Toplam yağışlardaki değişimin yönü ne olursa olsun, sıcaklık artışına bağı olarak şiddetli yağış hadiselerinde artış beklenmektedir. Küresel ısınmanın yağış şiddetleri üzerindeki etkisinin incelenmesine yönelik olarak son yıllarda dünyanın çeşitli bölgeleri için yapılan çalışmalarda yaygın olarak izlenen yol, günlük yağış miktarlarını farklı dilimlere (kategorilere) ayırıp her bir dilimdeki yağış miktarlarındaki ve/veya yağışlı gün sayılarındaki değişimleri incelemek şeklindedir (Arnone ve ark., 2013), İtalya'nın Sicilya adasında hafif $(0.1-4.0 \mathrm{~mm})$ yağış sayısında azalma eğilimi, ağır-şiddetli (>20 mm) yağış sayısında ise artış eğilimi saptamıştır. Homar ve ark. (2010), İspanya'nın Balear adalarında, \%95 düzeyinde olmak üzere, 1-4 mm kategorisindeki yağışı gün sayısında önemli artış eğilimi, 16-32 mm kategorisindeki yağışlı gün sayısında önemli azalış eğilimi saptamalarına karşın, diğer kategorilerdeki yağışlı gün sayılarında istatistiksel olarak önemli bir değişim olmadığını tespit etmişlerdir. Diğer yandan, toplam yağış içerisinde, $4 \mathrm{~mm}$ 'den az ve $64 \mathrm{~mm}$ 'den fazla yağışların oranında artış, 16-32 mm arasındaki yağışların oranında da azalış eğilimi saptamışlardır. Caloiero ve ark. (2016), İtalya'nın güneyindeki Calabria bölgesinde, yağışlı gün sayısında en düşük kategoride $(<4 \mathrm{~mm})$ belirgin bir artış eğilimi, diğer kategorilerde, özellikle kuvvetli (16-32 mm) ve çok kuvvetli (32-64 mm) yağış kategorilerinde, azalma eğilimi saptamışlardır. Yağış miktarında ise, alt yağış kategorilerinde artış, üst yağış kategorilerinde ise azalış eğilimi tespit etmişlerdir. Caloiero (2015), Yeni Zelanda'da gerek yağışı gün sayısında gerekse de yağış miktarında hiçbir kategoride belirgin bir eğilim olmadığını belirlemiştir. Yosef ve ark. (2009), İsrail'de, çok kuvvetli (16-32 mm/gün) yağış miktarında orta ve kuzey kesimlerde artış, güneyde azalış eğilimi; hafif-orta kuvvetteki (0-16 mm/gün) yağış miktarında ise kuzeyde artış, orta ve güney kesimlerde azalış eğilimi saptamıştır. Panthou ve ark. (2014), Afrika'nın Sahel bölgesinin orta kesimlerinde ekstrem yağış hadiselerinde artış olduğunu ve toplam yağış içerisinde ekstrem yağışlarının oranının 1970-1990 arasındaki \%17 değerinden 1991-2000 arasında \%19'a ve sonrasında 20012010 arasında \%21 değerine yükseldiğini bulmuştur. Alpert ve ark. (2002), İtalya'da aşırı yağışların (>128 mm) ve İspanya'da hafif $(0-4 \mathrm{~mm})$ ve şiddetli-aşırı (>64 mm) yağışların toplam yağış içindeki oranlarında artış olduğunu, fakat İsrail ve Kıbrıs'ta önemli bir değişim olmadığını tespit etmişlerdir. Karabulut ve Cosun (2009), Kahramanmaraş'ta toplam yağış miktarında önemli bir değişim olmadığını fakat yağışlı gün sayısında genel bir azalış eğilimi olduğunu tespit etmişlerdir. Koç ve İrdem (2007), yağış miktarında, hafif yağışlarda (<10.0 mm) özellikle kış mevsiminde Karadeniz bölgesinde istatistiksel olarak önemli artış eğilimi, normal (10.1-25.0 mm) ve orta şiddette $(25.1-50.0 \mathrm{~mm}$ ) yağışlarda Türkiye genelinde azalma eğilimi, yıllık ölçekte şiddetli (50.1-100.0 mm) yağışlarda Marmara Geçiş ve Karasal İç Anadolu yağış rejimi bölgelerinde artış eğilimi saptamasına karşın, çok şiddetli (>100.0 mm) yağışlarda ise kıyı bölgeleri haricinde genel bir eğilim saptamamıştır.

Bu çalışma, Batı Anadolu için ortalama sıcaklıktaki artışa bağlı olarak yağış şiddetlerindeki değişimleri belirlemek amacıyla yapılmıştır. Elde edilen bilgilerin, kentsel ve tarımsal su yönetiminde ve artması olası sel hadiselerine yönelik önlemlerin alınması hususunda yararlı olması beklenmektedir.

\section{MATERYAL VE YÖNTEM}

Çalışma Alanı: Çalışmada, Batı Anadolu'da Meteoroloji Genel Müdürlüğü (MGM) tarafından işletilen 32 meteoroloji istasyonunda 1966-2011 arasında kaydedilmiş günlük yağış değerleri kullanılmıştır (Şekil 1). Çalışma alanı, batıda Ege Denizi, güneyde Akdeniz ve kuzeyde Marmara denizi ile sınırlanmıştır.

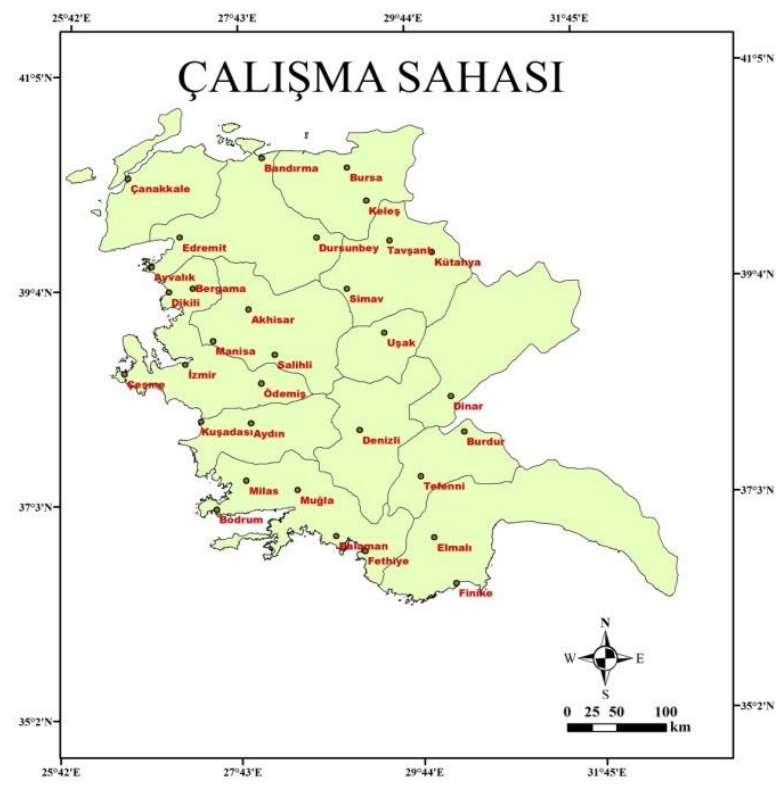

Şekil 1. Çalışma alanı ve istasyonların konumları

Veriler ve Kalite Kontrol: Çalışmada kullanılan günlük yağış verileri Meteoroloji Genel Müdürlüğü (MGM)'den temin edilmiştir ve 1966 ile 2011 yılları arasını kapsamaktadır. Veriler öncelikle basit bir kalite kontrol sürecinden geçirilmiştir. Buna göre, herhangi bir ay, 6 gün veya daha fazla eksik veriye sahipse, o ay eksik sayılmıştır. Ayrıca, herhangi bir yılda eksik bir ay olduğunda o yıl eksik olarak kabul edilmiştir (Chu ve ark., 2010).

Yağış Şiddeti İndisleri: Günlük yağış verileri Çizelge 1'de verilen yağış şiddeti aralıklarına ayrılmıştır (Alpert ve ark., 
2002; Homar ve ark., 2010). Her bir istasyon için Çizelge 1'deki yağış şiddeti kategorilerine göre beş zaman ölçeğinde (kış, ilkbahar, yaz, sonbahar ve yıllık) aşağıda verilen indisler üretilmiştir:

1) Yağışlı gün sayısı (YGS): ilgili kategoride meydana gelen yağış hadiselerinin sayısı

2) Yağış miktarı (YM): ilgili kategorideki yağış toplamı

3) Kategorideki yağış miktarının toplam yağışa oranı (ORN)

Aşırı yağış kategorisindeki yağış hadiseleri istatistiksel bir değerlendirmeye olanak sağlayacak sayıda olmadığı için değerlendirmeye alınmamıştır.

Çizelge 1. Yağış kategorileri ve aralıkları

\begin{tabular}{ll}
\hline Yağış Şiddeti Kategorisi & Günlük Toplam Yağış (mm) \\
\hline Hafif Yağış & $0.1-3.9$ \\
Orta Kuvvette Yağış & $4.0-15.9$ \\
Kuvvetli Yağış & $16.0-31.9$ \\
Çok Kuvvetli Yağış & $32.0-63.9$ \\
Şiddetli Yağış & $64.0-127.9$ \\
Aşırı Yağış & $\geq 128$
\end{tabular}

Mekânsal Değişim: Indis serilerinin 1966 ile 2011 yılları arasındaki ortalamalarının çalışma alanındaki mekânsal değişim haritaları Spline enterpolasyon metodu ile üretilmiştir (Li ve ark., 2011).

Zamansal Değişim: İndis serilerinin zamansal değişimlerinin (trendlerinin veya eğilimlerinin) istatistiksel önem düzeyi Mann-Kendall testi ile saptanmıştır (Tabari ve Talaee, 2011). $\mathrm{Bu}$ testte, $H_{0}$ Hipotezine göre, zaman içinde sıralanmış gözlemler zamandan bağımsız ve benzer dağılma sahip tesadüfi değişkenlerdir. $H_{1}$ Hipotezi zaman serisinde bir eğilim vardır. Test istatistiği aşağıdaki eşitlik yardımıyla hesaplanmaktadır (Salmi ve ark. 2002):

$$
S=\sum_{k=1}^{n-1} \sum_{j=k+1}^{n} \operatorname{sgn}\left(x_{j}-x_{k}\right)
$$

Eşitlikte,

$$
\operatorname{sgn}\left(x_{j}-x_{k}\right)=\left\{\begin{array}{l}
1, \text { ĕ } \text { er } x_{j}-x_{k}>0 \text { ise } \\
0, \text { ĕger } x_{j}-x_{k}=0 \text { ise } \\
-1, \text { ĕger } x_{j}-x_{k}<0 \text { ise }
\end{array}\right.
$$

Eğer veri sayısı 10'dan fazla ise, $S^{\prime}$ nin dağılımı için normal dağılım kullanılabilir ve $S^{\prime}$ nin varyansı aşağıdaki şekilde hesaplanır.

$$
\operatorname{VAR}(S)=\frac{1}{18}\left[n(n-1)(2 n+5)-\sum_{p=1}^{q} t_{p}\left(t_{p}-1\right)\left(2 t_{p}+5\right)\right]
$$

Eşitlikte, $q$ veriler içinde birbirine eşit değerlerin meydana getirdiği grupların sayısını ve $t_{p}$ de $p^{\prime}$ inci gruptaki verilerin sayısını gösterir. Ardından, $\operatorname{VAR}(S)$ ve $S$ kullanılarak, standart normal değişken $(Z)$ hesaplanır:

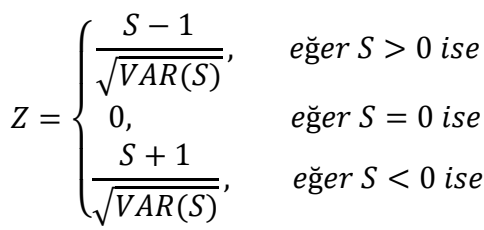

Eğer $Z$ pozitif ise artan yönde, $Z$ negatif ise azalan yönde bir eğilim söz konusudur. Belirli bir $\alpha$ önem düzeyinde (ikiyönlü test), eğilimin istatistiksel olarak önemli olup olmadığına, hesaplanan $Z$ değeri ile kritik $Z$ değerinin karşılaştırılmasıyla karar verilir. $Z$ 'nin mutlak değeri, standart normal dağılım tablosundan elde edilen $Z_{1-\alpha / 2}$ 'den büyük ise $H_{0}$ reddedilir. Bu çalışmada $\alpha$ önem düzeyi \%95 olarak alınmış ve eğilimlerin istatistiksel önemleri buna göre değerlendirilmiştir.

Seri korelasyonun etkisi: Mann-Kendall testini uygulayabilmek için, veriler arasında seri korelasyon olmamalıdır. Pozitif seri korelasyon varsa, Mann-Kendall testi trendi olduğundan fazla tahmin eder. Eğer seri AR(1) içermiyor fakat bir trende sahip ise, bu trend nedeniyle istatistiksel olarak önemli seri korelasyon elde edilebilir. Bu nedenle, eğilimi seri korelasyon ile birlikte ele alan TFPW (Trend-Free Prewhitening) süreci uygulanmıştır (Yue ve ark., 2002; Caloiero ve ark., 2011). Bu yaklaşımda, ilk olarak, serinin eğimi Sen'in eğim testi ile elde edilir ve bu eğim seriden çıkarılır. Eğimden ayıklanmış serinin lag-1 seri korelasyon katsayısı bulunur. Bulunan bu değer, \%5 düzeyinde istatistiksel olarak önemli değilse, Mann-Kendall testi orijinal seriye uygulanır. Eğer lag-1 seri korelasyon katsayısı istatistiksel olarak önemli ise, trendden ayıklanmış seriden $A R(1)$ süreci ayıklanır. Daha sonra, $A R(1)$ süreci sonundaki kalıntılarla başlangıçta Sen'in Eğim tahmincisi yöntemiyle elde edilen eğim birleştirilir. Sonuçta oluşan seri eğilim içermekte fakat seri korelasyon içermeyecektir. Son olarak, Mann-Kendall testi ile bu serideki trendin istatistiksel olarak önemli olup olmadığı saptanır. Diğer taraftan, eğer varyasyon katsayısı çok düşük $(<0.1)$ ise, "prewhitening" süreci uygulanmayabilir (Bayazit ve Önöz, 2007). Bu çalışmada da varyasyon katsayısının 0.1 ve daha düşük olduğu serilerde "prewhitening" uygulanmamıştır.

Eğilimlerin Büyüklükleri: Eğilimlerin büyüklükleri Sen'in Eğim Tahmincisi (Sen's Slope Estimator) yöntemi kullanılarak saptanmıştır (Salmi ve ark., 2002). Bu yöntemde trendin büyüklüğü $(\beta)$ serideki tüm veri çiftlerinin medyanıdır:

$$
\beta=\operatorname{Medyan}\left(\left(x_{j}-x_{k}\right) /(j-k)\right), \forall j>k
$$




\section{BULGULAR VE TARTIŞMA}

Bu çalışmada, ilk olarak, YGS, YM ve ORN'nin, tüm zaman ölçeklerindeki (kış, ilkbahar, yaz, sonbahar ve yıllık) ve tüm kategorilerdeki 1966 ile 2011 yılları arasındaki ortalamalarının çalışma alanındaki mekânsal değişimi incelenmiş ve şiddetli yağış kategorisinde yıllık ölçekteki mekânsal değişim haritaları Şekil 2, Şekil 3 ve Şekil 4'de örnek olarak verilmiştir. Haritaların incelenmesinden, alt

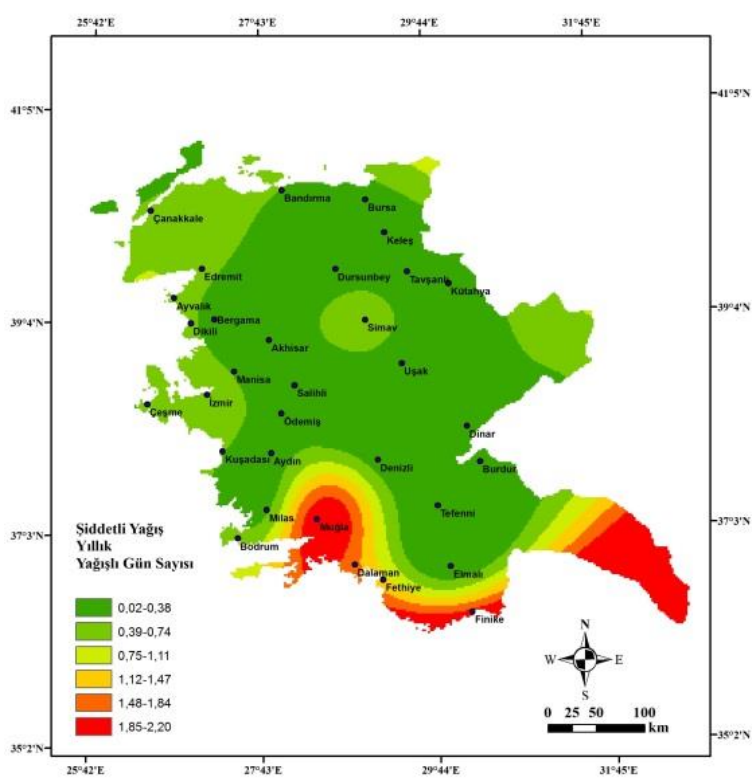

Şekil 2. Şiddetli yağış kategorisinde yıllık ölçekte YGS'nin çalışma alanındaki mekânsal değişimi

kategorilerde (hafif ve orta kuvvette yağış), çoğu zaman ölçeğinde, YGS ve YM'nin güneybatıdan kuzeydoğuya, ORN'nin ise batıdan doğuya artış eğilimi gösterdiği saptanmıştır. Örneğin, kış, ilkbahar, yaz, sonbahar mevsimleri ile yıllık ölçekte ve hafif yağış kategorisinde, kuzeydoğuda YGS, sırasıyla, 27, 26, 10, 18 ve 80 gün, YM ise $33,33,12,21$ ve $94 \mathrm{~mm}$ 'dir. ORN de, yine aynı dönemlerde ve kategoride, çalışma alanının doğu kesimlerinde, yine sırasıyla, \%6, \%6, \%2, \%4 ve \%19'dur. Orta kategoride (kuvvetli yağış kategorisi), hemen hemen tüm zaman ölçeklerinde, YGS ile YM'nin kuzeydoğu ile güneybatıda, ORN'nin ise batıda yüksek değerler aldığı görülmektedir. Üst kategorilerde (çok kuvvetli ve şiddetli yağışlar) ise, her üç indisin de yaz mevsiminde kuzey kesimlerde, diğer dönemler de güneyde yüksek olduğu saptanmıştır. Örneğin, şiddetli yağışlar, yaz mevsiminde kuzeyde (Bandırma civarında) toplam yağışın $\% 0.5^{\prime}$ ni, yıllık ölçekte güneyde (Muğla ve Finike'de) toplam yağışın \%15'ini oluşturmaktadır. YGS, YM ve ORN indislerinin tüm zaman ölçeklerindeki ve tüm kategorilerdeki ortalamalarının

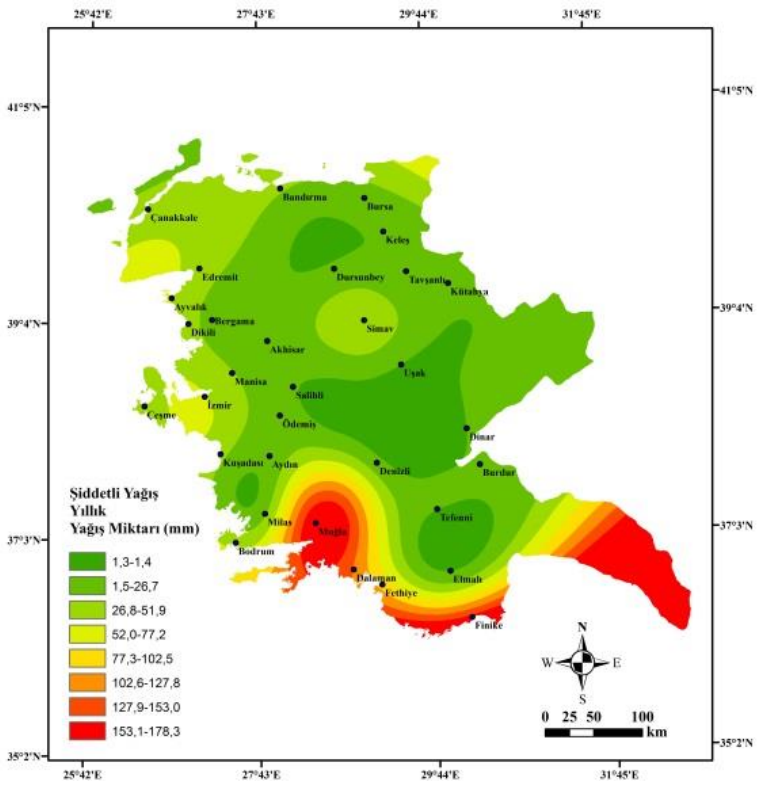

Şekil 3. Şiddetli kategorisinde yıllık ölçekte YM'nin çalışma alanındaki mekânsal değişimi

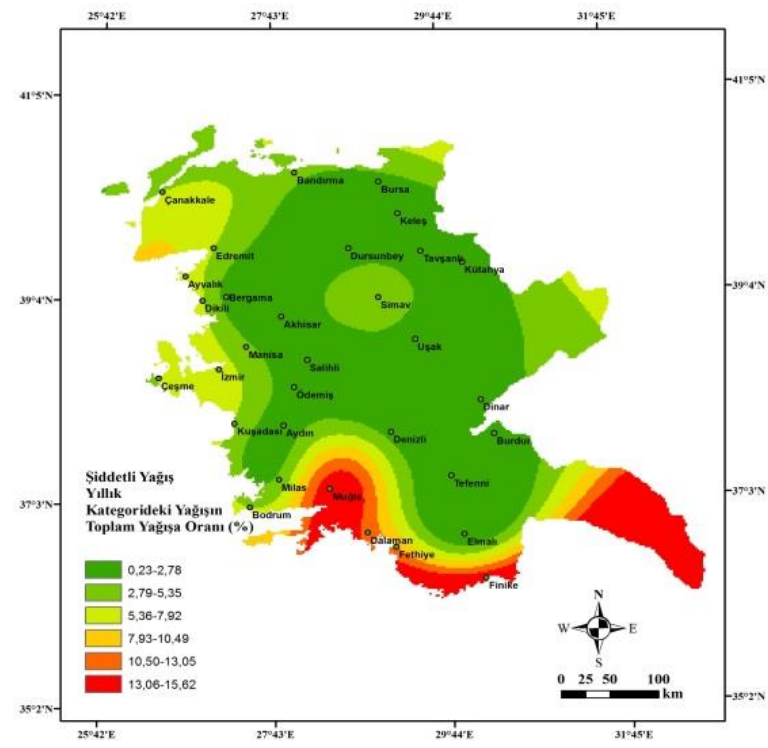

Şekil 4. Şiddetli yağış kategorisinde yıllık ölçekte ORN'nin çalışma alanındaki mekânsal değişimi

mekansal değişimleri birlikte değerlendirildiğinde, sel hadisesine yol açma potansiyeline daha fazla sahip olan üst kategori yağışların yaz mevsiminde kuzeyde (BandırmaÇanakkale hattında), diğer mevsimlerde ise güneyde (Muğla-Finike hattında), çalışma alanının diğer kesimlerine nazaran daha fazla meydana geldiği saptanmıştır. Bu bulgu, söz konusu lokasyonlarda sel riskinin nispeten daha fazla olduğunu göstermektedir. 
YGS'nin zamansal değişimleri incelendiğinde; çok büyük çoğunluğu \%95 düzeyinde istatistiksel olarak önemli olmamakla birlikte, yağış şiddeti arttıkça 32 istasyondan artış eğilimi gösteren istasyonların sayısının tüm mevsimlerde ve yıllık ölçekte arttığı görülmektedir (Çizelge 2). Örneğin, kış mevsiminde hafif yağış kategorisinde sadece 5 istasyonda artış eğilimi saptanmışken, bu değer orta kuvvette 2, kuvvetlide 2, çok kuvvetlide 12 ve şiddetlide 13'tür. Artış eğilimindeki istasyonların sayısındaki artışa bağlı olarak azalan yönde eğilim gösteren istasyonların sayısında da azalma görülmektedir. Yine kış mevsiminde, azalış gösteren istasyonların sayısı, sırasıyla, 27, 30, 30, 20 ve 19 olarak gerçekleşmiştir. Fakat eğilimlerin çok büyük bir kısmı \%95 düzeyinde istatistiksel olarak önemsizdir. Bunun istisnası, hafif yağış kategorisinde, özellikle yıllık ölçekte, azalan yöndeki eğilimlerdir. Hafif yağış kategorisinde kış mevsiminde 27 istasyonun $8^{\prime}$ inde, ilkbahar mevsiminde 30 istasyonun 10'unda, yaz mevsiminde 23 istasyonun $8^{\prime}$ inde, sonbahar mevsiminde 25 istasyonun 4'ünde ve yıllık olarak 31 istasyonun $18^{\prime}$ inde azalan eğilimler istatistiksel olarak önemlidir. Buna karşın daha üst yağış kategorilerinde YGS'de kayda değer istatistiksel olarak önemli artış eğilimi görülmemektedir. Bir başka ifadeyle, sel hadisesine yol açma eğilimi olan üst kategori yağış hadiselerinin sayısında istatistiksel olarak önemli bir eğilim saptanmamıştır.

Çizelge 2. YGS' de artış ve azalış saptanan istasyonların sayıları

\begin{tabular}{|c|c|c|c|c|c|c|c|c|c|c|}
\hline \multirow{2}{*}{ Kategori } & \multicolumn{2}{|l|}{ Kış } & \multicolumn{2}{|c|}{ ilkbahar } & \multicolumn{2}{|l|}{ Yaz } & \multicolumn{2}{|c|}{ Sonbahar } & \multicolumn{2}{|l|}{ Yıllık } \\
\hline & Artış & Azalış & Artış & Azalış & Artış & Azalış & Artış & Azalış & Artış & Azalış \\
\hline Hafif Yağış & $5(0)$ & $27(8)$ & $2(1)$ & $30(10)$ & $9(0)$ & $23(8)$ & $7(0)$ & $25(4)$ & $1(1)$ & $31(18)$ \\
\hline $\begin{array}{l}\text { Orta Kuvvetli } \\
\text { Yağış }\end{array}$ & $2(0)$ & $30(2)$ & $14(0)$ & $18(0)$ & $13(0)$ & $19(2)$ & $18(1)$ & $14(0)$ & $3(0)$ & $29(5)$ \\
\hline Kuvvetli Yağış & $2(0)$ & $30(0)$ & $16(0)$ & $16(0)$ & $11(0)$ & $21(1)$ & $5(0)$ & $27(2)$ & $14(0)$ & $18(0)$ \\
\hline $\begin{array}{l}\text { Çok Kuvvetli } \\
\text { Yağış }\end{array}$ & $12(0)$ & $20(0)$ & $9(0)$ & $23(0)$ & $16(0)$ & $16(0)$ & $26(3)$ & $6(0)$ & $20(0)$ & $12(1)$ \\
\hline Şiddetli Yağış & $13(0)$ & $19(1)$ & $22(0)$ & $10(1)$ & $28(0)$ & $4(0)$ & $28(0)$ & $4(0)$ & $17(2)$ & $15(0)$ \\
\hline
\end{tabular}

Parantez içindeki değerler \%95 düzeyinde istatistiksel olarak önemli olanların sayılarını göstermektedir

Çizelge 3. YM'de artış ve azalış saptanan istasyonların sayıları

\begin{tabular}{|c|c|c|c|c|c|c|c|c|c|c|}
\hline \multirow{2}{*}{ Kategori } & \multicolumn{2}{|l|}{ Kış } & \multicolumn{2}{|c|}{ ilkbahar } & \multicolumn{2}{|l|}{ Yaz } & \multicolumn{2}{|c|}{ Sonbahar } & \multicolumn{2}{|l|}{ Yıllık } \\
\hline & Artış & Azalış & Artış & Azalış & Artış & Azalış & Artış & Azalış & Artış & Azalış \\
\hline Hafif Yağış & $4(0)$ & $28(1)$ & $3(0)$ & $29(4)$ & $7(0)$ & $25(4)$ & $11(0)$ & $21(2)$ & $1(0)$ & $31(14)$ \\
\hline $\begin{array}{l}\text { Orta Kuvvetli } \\
\text { Yağış }\end{array}$ & $1(0)$ & $31(1)$ & $14(0)$ & $18(0)$ & $13(0)$ & $19(1)$ & $17(1)$ & $15(1)$ & $5(0)$ & $27(2)$ \\
\hline Kuvvetli Yağış & $4(0)$ & $28(0)$ & $18(0)$ & $14(0)$ & $12(0)$ & $20(1)$ & $29(3)$ & $3(0)$ & $13(0)$ & $19(0)$ \\
\hline $\begin{array}{l}\text { Çok Kuvvetli } \\
\text { Yağış }\end{array}$ & $10(0)$ & $22(0)$ & $8(0)$ & $24(0)$ & $15(0)$ & $17(0)$ & $25(4)$ & $7(0)$ & $18(0)$ & $14(0)$ \\
\hline Şiddetli Yağış & $12(0)$ & $20(1)$ & $22(0)$ & $10(1)$ & $28(0)$ & $4(0)$ & $30(0)$ & $2(0)$ & $17(3)$ & $15(0)$ \\
\hline
\end{tabular}

Parantez içindeki değerler \%95 düzeyinde istatistiksel olarak önemli olanların sayılarını göstermektedir
YM indisinin zamansal değişim analizi sonucunda hafif yağış kategorisinde yıllık zaman ölçeği haricinde tüm yağış kategorilerinde ve tüm zaman ölçeklerinde \%95 düzeyinde istatistiksel olarak önemsiz değişimlerin baskın olduğu saptanmıştır (Çizelge 3). Hafif yağış kategorisinde yıllık ölçekte 14 istasyonda, YGS'de olduğu gibi, \%95 düzeyinde önemli azalış eğilimi dikkati çekmektedir. Diğer taraftan, şiddetli yağış kategorisinde yıllık ölçekte istatistiksel olarak önemli artış eğilimi saptanan Burdur, Kuşadası ve Çanakkale istasyonlarında sel hadiselerine yol açabilecek yağışların arttığı söylenebilir.

ORN indisinin zamansal değişim analizi, tüm kategorilerde ve zaman ölçeklerinde söz konusu dönem içinde \%95 düzeyinde genelde istatistiksel olarak önemli bir zamansal değişim meydana gelmediğini göstermektedir (Çizelge 4). Hafif yağış kategorisinde kış ve ilkbahar mevsimlerinde 2'şer istasyonda, yaz mevsiminde 3 istasyonda, sonbahar mevsiminde 1 istasyonda ve yıllık olarak 5 istasyonda istatistiksel olarak önemli azalış tespit edilmişken sadece ilkbahar mevsiminde 1 istasyonda istatistiksel olarak önemli artış söz konusudur. Orta kuvvetli yağış kategorisinde, kış mevsiminde 3 istasyonda ve yaz mevsiminde 1 istasyonda istatistiksel olarak önemli azalış, sonbahar mevsiminde 1 istasyonda istatistiksel olarak önemli artış tespit edilmiştir. Kuvvetli yağış kategorisinde kış ve yaz mevsimlerinde 1 'er istasyonda istatistiksel olarak önemli azalış, sonbahar

Parantez içindeki değerler \%95 düzeyinde istatistiksel olarak önemli olanlarin saylarını göstermektedir 
Çizelge 4. ORN'de artış ve azalış saptanan istasyonların sayıları

\begin{tabular}{|c|c|c|c|c|c|c|c|c|c|c|}
\hline \multirow{2}{*}{ Kategori } & \multicolumn{2}{|l|}{ Kış } & \multicolumn{2}{|c|}{ ilkbahar } & \multicolumn{2}{|l|}{ Yaz } & \multicolumn{2}{|c|}{ Sonbahar } & \multicolumn{2}{|l|}{ Yıllık } \\
\hline & Artış & Azalış & Artış & Azalış & Artış & Azalış & Artış & Azalış & Artış & Azalış \\
\hline Hafif Yağış & $8(0)$ & $24(2)$ & $7(1)$ & $25(2)$ & $8(0)$ & $24(3)$ & $17(0)$ & 15(1) & $4(0)$ & $28(5)$ \\
\hline $\begin{array}{l}\text { Orta Kuvvetli } \\
\text { Yağış }\end{array}$ & $4(0)$ & $28(3)$ & $22(0)$ & $10(0)$ & $11(0)$ & 21(1) & 21(1) & $11(0)$ & 10(0) & $22(0)$ \\
\hline Kuvvetli Yağış & $4(0)$ & $28(1)$ & $23(0)$ & $9(0)$ & $11(0)$ & $21(1)$ & $28(3)$ & $4(0)$ & $18(1)$ & $14(0)$ \\
\hline $\begin{array}{l}\text { Çok Kuvvetli } \\
\text { Yağış }\end{array}$ & $11(0)$ & $21(0)$ & $9(0)$ & $23(0)$ & $15(0)$ & $17(0)$ & $28(4)$ & $4(0)$ & 19(1) & $13(0)$ \\
\hline Şiddetli Yağış & $12(0)$ & 20(1) & $22(0)$ & 10(0) & $28(0)$ & $4(0)$ & 30(0) & $2(0)$ & 19(1) & $13(0)$ \\
\hline
\end{tabular}

Parantez içindeki değerler \%95 düzeyinde istatistiksel olarak önemli olanların sayılarını göstermektedir

mevsiminde 3 istasyonda ve yıllık olarak 1 istasyonda önemli artış saptanmıştır. Çok kuvvetli yağış kategorisinde ise sonbahar mevsiminde 4 istasyonda ve yıllık ölçekte 1 istasyonda önemli artış söz konusudur. Şiddetli yağış kategorisinde kış mevsiminde 1 istasyonda önemli azalış tespit edilirken, yıllık ölçekte 1 istasyonda istatistiksel olarak önemli artı̧̧ tespit edilmiştir.

Küresel ortalama sıcaklık 1880 ile 2012 arasında $0.85^{\circ} \mathrm{C}^{\prime}$ lik bir artış göstermiştir (IPCC, 2013). Ülkemizin ortalama sıcaklığının da $1901-2014$ yılları arasında $1.0{ }^{\circ} \mathrm{C}$ yükseldiği saptanmıştır (Hadi ve Tombul, 2018). Küresel ısınmayla birlikte toplam yağış miktarlarında da değişim söz konusudur. Bu değişimler kimi coğrafyalarda artış şeklinde, kimilerinde azalma yönündedir. Doğu Karadeniz bölgesi haricinde ülkemizin diğer bölgelerinde yağış toplamlarında genel bir azalma meydana geldiği saptanmış ve bu azalmanın, içinde bulunduğumuz yüzyıl içerisinde genel olarak devam edeceği tahmin edilmektedir (Akçakaya ve ark., 2015; Önol ve Unal, 2014). Bunun yanında, hava sıcaklığının yükselmesi sonucunda atmosferin nem tutma kapasitesi artmakta ve bunun da şiddetli yağış hadiselerinin daha sık meydana gelmesine neden olması söz konusudur. Bu çalışmada, sıcaklık artışıla birlikte, Batı Anadolu'da yağı̧ şiddetlerinde değişim meydana gelip gelmediğini incelemek amacıyla yapılmıştır. Bu amaç doğrultusunda, Anadolu'nun batısında yer alan 32 istasyonda 1966 ile 2011 yılları arasında kaydedilen günlük yağış değerleri farklı yağış şiddeti kategorilerine ayrılmıs ve her kategorideki yağış hadiselerinin frekansı, miktarı ve toplam yağış içindeki oranlarının söz konusu dönem içindeki zamansal değişimleri ile ortalamalarının çalışma alanı içindeki mekânsal değişimleri incelenmiştir.

Mekânsal değişimler incelendiğinde, indis-kategori-mevsim kombinasyonuna bağlı olarak, genelde kuzeydoğugüneybatı doğrultusunda azalış veya artış desenleri gözlenmiştir. En belirgin bulgu, sel hadisesine yol açma potansiyeline daha fazla sahip olan üst kategori yağışların yaz mevsiminde kuzeyde (Bandırma-Çanakkale hattında), diğer mevsimlerde ise güneyde (Muğla-Finike hattında), çalışma alanının diğer kesimlerine nazaran daha fazla meydana geldiğidir.

Zamansal değişim analizleri, hava sıcaklığındaki artışa rağmen, Batı Anadolu'da 1966 ile 2011 yılları arasında özellikle orta ve üst kategorilerdeki yağış şiddetlerinde yağışlı gün sayısında, yağış miktarında ve kategorideki yağışın toplam yağışa oranında istatistiksel olarak önemli bir değişim olmadığını ortaya koymuştur. Diğer taraftan, Yeşilırmak ve Atatanır (2017), hemen hemen aynı istasyonlarda ve yine 1966 ile 2011 yılları arasında toplam yıllık yağışlarda \%95 düzeyinde istatistiksel olarak önemsiz azalış eğilimleri saptamışır. Yani, yıllık ölçekte değerlendirildiğinde, toplam yağışlarda önemli bir değişim olmadığı gibi yağış şiddeti indislerinde (yağışı gün sayısı, yağış miktarı ve kategorideki yağış miktarına oranı) de önemli bir değişim söz konusu olmamıştır. Bu çalışmada, aynı zamanda, söz konusu indislerde mevsimlik ölçekte de istatistiksel olarak önemli bir değişim saptanmamıştır. Diğer taraftan, dünyanın bazı bölgelerinde yağış toplamlarında azalmaya rağmen ekstrem yağışlarda artışlar da söz konusudur. Alpert ve ark. (2002), toplam yağışların azalmasına rağmen, İtalya'da 128 mm'den yüksek günlük yağışlarda, İspanya'da $0-4 \mathrm{~mm}$ arasındaki ve $64 \mathrm{~mm}$ 'den yüksek günlük yağışlarda artış eğilimi saptamışlardır. Bu bulgular, aynı zamanda, iklim değişikliğinin zamansal ve mekânsal olarak homojen olmadığı bilgisini doğrulamaktadır.

Alpert ve ark. (2002), kuvvetli El-Nino yıllarının İtalya'daki aşırı yağışlarla olan ilişkisini vurgulamıştır. Ülkemizdeki yağışlar da El-Nino Güneyli Salınım (ENSO), Kuzey Atlantik Salınımı (NAO), Kuzey Denizi-Hazar Deseni (NCP) (Kutiel ve ark., 2002; Kutiel ve Türkeş, 2005) gibi uzak-etkileşim desenlerinin etkisi altındadır. Bu gibi uzak-etkileşim desenlerinin ülkemizdeki, özellikle Batı Anadolu'daki ekstrem yağışlar üzerindeki etkilerinin araştııııması, Batı Anadolu için saptanan "beklenti" ile "gözlem" arasındaki farklıı̆ın açıklanmasına katkıda bulunabilir. 


\section{SONUÇ}

Çalışmanın mekânsal değişim analizi, çalışma alanının yaz mevsiminde kuzeyinde (Bandırma-Çanakkale hattında), diğer mevsimlerde ise güneyinde (Muğla-Finike hattında), sel riskinin çalışma alanının diğer kesimlerine nazaran nispeten daha fazla olduğunu ortaya koymuştur. Zamansal değişim analizinde ise, ortalama hava sıcaklığındaki artışa rağmen, özellikle orta ve üst yağış şiddeti kategorilerinde yağışı gün sayısında, yağış miktarında ve kategorideki yağışın toplam yağışa oranında istatistiksel olarak önemli bir değişim olmadığı belirlenmiştir. Başka bir ifadeyle, ortalama sıcaklık artışına rağmen, şiddetli yağışlarda artış meydana gelmemiştir.

\section{KAYNAKLAR}

Akçakaya A, Sümer UM, Demircan M, Demir Ö, Atay $H$, Eskioğlu O, Gürkan H, Yazıcı B, Kocatürk A, Şensoy $S$, Bölük $E$, Arabacı $H$, Açar $Y$, Ekici $M$, Yağan $S$, Çukurçayır F (2015) Yeni Senaryolar ile Türkiye İklim Projeksiyonları ve İklim Değişikliği. TR2015-CC. Meteoroloji Genel Müdürlüğü. Araştırma Dairesi Başkanlığı Klimatoloji Şube Müdürlüğü, Ankara.

Alpert P, Ben-Gai T, Baharad A, Benjamini Y, Yekutieli D, Colacino M, Diodato L, Ramis C, Homar V, Romero R, Michaelides S, Manes A (2002) The paradoxical increase of mediterranean extreme daily rainfall in spite of decrease in total values. Geophysical Research Letters 29: 1536.

Arnone E, Pumo D, Viola F, Noto LV, La Loggia G (2013) Rainfall statistics changes in Sicily. Hydrology and Earth System Sciences 17: 2449-2458.

Bayazıt M, Önöz B (2007) To Prewhitten or not to prewhitten in trend analysis. Hydrological Sciences Journal 52: 611-624.

Caloiero T (2015) Analysis of rainfall trend in New Zealand. Environmental Earth Sciences 73: 62976310.

Caloiero T, Coscarelli R, Ferrari E, Sirangelo B (2016) Trends in the daily precipitation categories of Calabria (Southern Italy). Procedia Engineering 162: 32-38.

Caloiero T, Coscarelli R, Ferrari E, Mancini M (2011) Trend detection of annual and seasonal rainfall in Calabria (Southern Italy). International Journal of Climatology 31: 44-56.

Chu P-S, Chen YR, Schroeder TA (2010) Changes in precipitation extremes in the Hawaiian Islands in a warming climate. Journal of Climate 23: 4881-4900.

Cubasch U, Wuebbles D, Chen D, Facchini MC, Fram D, Mahowald N, Winther G (2013) Introduction. In: Stocker TF, Qin D, Plattner G-K, Tignor M, Allen SK, Boschung J, Nauels A, Xia Y, Bex V, Midgley PM (eds) Climate Change 2013: The Physical Science Basis. Contribution of working group I to the Fifth Assessment Report of the Intergovernmental Panel on Climate Change, Cambridge University Press, Cambridge.
AĞBAŞ i, YEŞiLIRMAK E

Fowler AM, Hennessy KJ (1995) Potential impacts of global warming on the frequency and magnitude of heavy precipitation. Natural Hazards 11: 283-303.

Hadi SJ, Tombul M (2018) Long-term spatiotemporal trend analysis of precipitation and temperature over Turkey. Meteorological Applications 25: 445-455.

Homar V, Ramis C, Romero R, Alonso S (2010) Recent trends in temperature and precipitation over the Balearic Islands (Spain). Climatic Change 98: 199-211.

IPCC (2013) Climate Change 2013: The Physical Science Basis. In: Stocker TF, Qin D, Plattner GK, Tignor M, Allen SK, Boschung J, Nauels A, Xia Y, Bex V, Midgley PM (eds.), Contribution of Working Group I to the Fifth Assessment Report of the Intergovernmental Panel on Climate Change, Cambridge University Press, Cambridge, United Kingdom and New York, NY, USA.

Karabulut M, Cosun F (2009) Kahramanmaraş ilinde yağışların trend analizi. Coğrafi Bilimler Dergisi 7: 6583.

Koç T, İrdem C (2007) Türkiye'de yağışların şiddet bakımından zamansal ve alansal değişkenliği. Türk Coğrafya Dergisi 49: 1-42.

Kumar V, Jain SK (2010) Trends in seasonal and annual rainfall and rainy days in Kashmir Valley in the last century. Quaternary International 212: 64-69.

Kutiel H, Maheras P, Türkeş M, Paz S (2002) North Sea Caspian Pattern (NCP) - an upper level atmospheric teleconnection affecting the eastern Mediterranean implications on the regional climate. Theoretical and Applied Climatology 72: 173- 192.

Kutiel H, Türkeş M (2005) New evidence for the role of the north sea-caspian pattern on the temperature and precipitation regimes in continental central Turkey. Geografiska Annaler: Series A, Physical Geography 87: 501-513.

Li Z, He Y, Wang C, Wang X, Xin H, Zhang W, Cao W (2011) Spatial and temporal trends of temperature and precipitation during 1960-2008 at the Hengduan Mountains, China. Quaternary International 236: 127142.

Mishra AK, Singh VP (2010) Changes in extreme precipitation in Texas. Journal of Geophysical Research 115: 14106.

Önol B, Unal YS (2014) Assessment of climate change simulations over climate zones of Turkey. Regional Environmental Change 14: 1921-1935.

Panthou G, Vischel T, Lebel T (2014) Recent trends in the regime of extreme rainfall in the Central Sahel. International Journal of Climatology 34: 39984006.

Salmi T, Maata A, Antilla P, Ruoho-Airola T, Amnell T (2002) Detecting trends of annual values of atmsopheric pollutants by the Mann-Kendall test and Sen's slope estimates-the excel template application Makesens, Finnish Meteorological Institute, Helsinki, Finland.

Tabari H, Talaee PH (2011) Temporal variability of precipitation over Iran: 1966-2005. Journal of Hydrology 396: 313-320. 
Yeşilırmak E, Akçay S, Dağdelen N (2011) Büyük Menderes havzasında yıllık toplam yağışların zamansal değişimleri. ADÜ Ziraat Fakültesi Dergisi 8: 37-46.

Yeşilırmak E, Atatanır L (2017) Spatial and temporal patterns of dry spells in western Turkey. Environmental Earth Sciences 76:594.
Yosef $Y$, Saaroni H, Alpert $P$ (2009) Trends in daily rainfall intensity over Israel 1950/1-2003/4. Open Atmospheric Science Journal 3: 196-203.

Yue S, Pilon P, Phinney B, Cavadias G (2002) The influence of autocorrelation on the ability to detect trend in hydrological series. Hydrological Processes 16: 18071829. 